\title{
Evaluated the lead levels at boiling water in clay pots and impact of the lead contaminated diet on nutritional, biochemical status of male rats
}

\author{
Mona S. El Kutry ${ }^{*}$ and El-Sayeda G.E. El-Sahar
}

\begin{abstract}
Background: For centuries, people have been using clay or earthen pots for cooking. Also, many studies indicated a contrariety from safety or danger of it. Our study aims to assess the lead concentration in boiling water in clay pots. Contaminated the diet with lead acetate and evaluated the nutritional, biochemical statues, and histological studies for male albino rats.

Step A: Ten samples of the distilled water and/or tap water were boiled in the clay pots (glaze and/or unglazed). Then, it was left to cool for either 2 or $4 \mathrm{~h}$.

Step B: Thirty male albino rats divided three groups as follows: group 1: fed on basal diet (negative control), group2: fed on basal diet+466.5 mg/kg body wt of lead acetate $\left(L_{1}\right)$, group 3: fed on the basal diet+933 mg/kg body wt of lead acetate $\left(L_{2}\right)$.

Results: Lead concentrations in distilled water samples boiled in glazed clay pots were significantly higher than the negative control. Tap water samples boiled in glazed clay pots showed lead concentrations that were significantly higher than that of the positive control. Whereas, lead concentrations in distilled water boiled in the unglazed clay pots and left to cool for either $2 \mathrm{~h}$ or $4 \mathrm{~h}$ showed no significant differences compared to the negative control. Besides, rats fed $L_{1}$ and $L_{2}$ of lead acetate had a significant decrease in BWG and food intake compared with the negative control group. Also, rats were given lead acetate at the two levels $\left(L_{1}\right.$ and $\left.L_{2}\right)$ had significantly lower levels of hemoglobin, RBCs, and WBCs compared with rats fed basic diet only (negative control). Data illustrated that the rats of groups 2 and 3 have increased significantly in GOT concentration of serum, a significant increase in cholesterol and triglycerides levels, and increased significantly in creatinine, urea, and lead concentration in serum compared with the (negative control).
\end{abstract}

Conclusion: Bring the clay pots for cooking would be unglazed and natural forming, even if glazed may be having certified a lead free.

Keywords: Lead acetate, Clay glazed, Clay unglazed, Water, Liver, Kidney function

\footnotetext{
*Correspondence: drmonaelkutry@gmail.com; trainerms2016@gmail.com Home Economics Department, Faculty of Specific Education, Ain shams University, Cairo, Egypt
}

\section{Springer Open}

(c) The Author(s). 2020 Open Access This article is licensed under a Creative Commons Attribution 4.0 International License, which permits use, sharing, adaptation, distribution and reproduction in any medium or format, as long as you give appropriate credit to the original author(s) and the source, provide a link to the Creative Commons licence, and indicate if changes were made. The images or other third party material in this article are included in the article's Creative Commons licence, unless indicated otherwise in a credit line to the material. If material is not included in the article's Creative Commons licence and your intended use is not permitted by statutory regulation or exceeds the permitted use, you will need to obtain permission directly from the copyright holder. To view a copy of this licence, visit http://creativecommons.org/licenses/by/4.0/. 


\section{Background}

For centuries, we have been using clay or earthen pots (glazed and unglazed) for cooking. Food cooked in clay pots will remain moist and hot, enabling cooking with lesser amounts of liquid and fat than usual. In addition, it has been reported that food cooked in clay pots has a significantly lower load of pathogenic microorganisms than that cooked in aluminum pots [1]. One concern that people have about cooking in ceramic pots is that a glaze may contain lead and/or cadmium, which could leach into foods if the glaze is improperly formulated, applied, or fired [1]. All pottery sold in the USA for cooking must be tested and certified as safe by the US Food and Drug Administration [2].

Lead $(\mathrm{Pb})$ is one of the widespread environmental pollutants that induce a broad range of physiological and biochemical dysfunctions in animals [3]. Lead exposure, even at low concentrations, is toxic to animals and humans [4]. Lead concentration of $5 \mu \mathrm{g} / \mathrm{L}$ in drinking water may lead to a total intake of lead ranging from 3.8 $\mu \mathrm{g} /$ day in an infant up to $10 \mu \mathrm{g} /$ day in an adult [5]. Lead toxicity can be associated with gastrointestinal disturbances such as nausea, vomiting, diarrhea, and in severe cases coma and death [5]. Chronic lead exposure can adversely affect hemoglobin formation and cause anemia. In addition, it may interfere with calcium and vitamin D metabolism, and delay nervous system development causing mental retardation [6]. Lead is absorbed through the gastrointestinal tract. Around 70 to $90 \%$ of lead goes into the bones, kidneys, and liver, with subsequent organ dysfunction $[7,8]$.

Therefore, the aim of the current study was to assess lead concentration in clay pots' boiling water and to evaluate the nutritional, biochemical, and histopathological effects of lead acetate exposure in male albino rats.

\section{Methods}

\subsection{Step A}

Both clay pots (natural clay, non-pigmented) and ceramic pots (clay covered with a glaze layer) were purchased from the local Egyptian market (Figs. 1 and 2). Water was boiled in both glazed and unglazed clay pots.

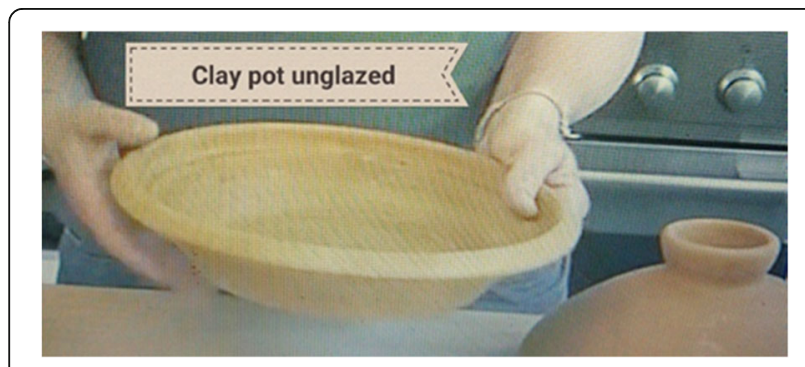

Fig. 1 Clay pot unglazed

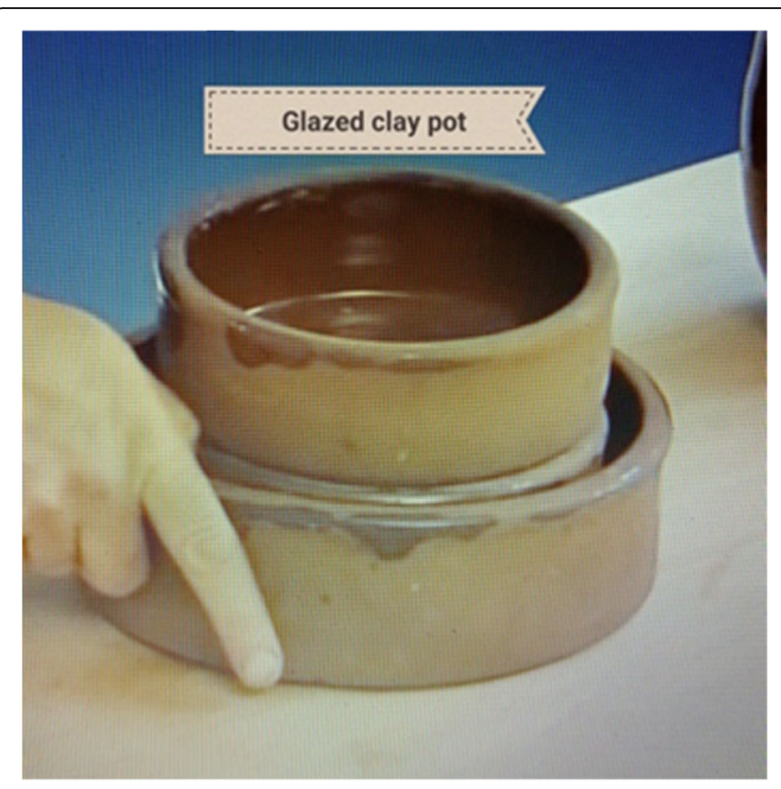

Fig. 2 Clay pot glazed

Then, it was left to cool for either 2 or $4 \mathrm{~h}$. Water samples (Sp) were classified as follows:

Sp 1: distilled water (negative control); Sp 2: tap water (positive control); Sp 3: distilled water boiled in an unglazed clay pot and left to cool for $2 \mathrm{~h}$; Sp 4: distilled water boiled in an unglazed clay pot and left to cool for $4 \mathrm{~h}$; Sp 5: distilled water boiled in glazed clay pot and left to cool for $2 \mathrm{~h}$; Sp 6: distilled water boiled in glazed clay pot and left to cool for $4 \mathrm{~h}$; Sp 7: tap water boiled in an unglazed clay pot and left to cool for $2 \mathrm{~h}$; Sp 8: tap water boiled in an unglazed clay pot and left to cool for $4 \mathrm{~h}$; Sp 9: tap water boiled in glazed clay pot and left to cool for $2 \mathrm{~h}$; and Sp 10: tap water boiled in glazed clay pot and left to cool for $4 \mathrm{~h}$.

\subsubsection{Collection of water samples}

Tap water was collected in clean, 6-L capacity plastic containers from different three locations of Cairo, Egypt. The taps were pliable to run for at least 5 min before filling. Each sample was collected three times during a period of about $5 \mathrm{~h}$ for each location.

\subsubsection{Samples preparation and analysis}

All pots were properly washed several times using distilled water before starting the experiment. Either distilled water or tap water was boiled in the pots. Water was left to cool for $2 \mathrm{~h}$ or $4 \mathrm{~h}$. Then, it was collected carefully in polythene bottles $(250 \mathrm{~mL})$, properly labeled, and sent for analysis. The ten samples were taken to the Desert Research Center, Cairo, Egypt for chemical analysis according to the Association of Official Analytical Chemists (AOAC) [9]. 
Table 1 Concentrations of Pb in distilled water boiled in clay pots

\begin{tabular}{|c|c|c|c|c|c|}
\hline \multirow{2}{*}{$\frac{\text { Parameter }}{\text { Groups }}$} & \multirow{2}{*}{$\begin{array}{l}\text { Distilled water (Sp 1) (negative control) (Pb } \mu \mathrm{g} / \mathrm{L}) \\
<\mathrm{DL}\end{array}$} & \multicolumn{2}{|c|}{ Clay pot natural (unglazed) (Pb $\mu \mathrm{g} / \mathrm{L}$ ) } & \multicolumn{2}{|c|}{ Clay pot glazed $(\mathrm{Pb} \mu \mathrm{g} / \mathrm{L})$} \\
\hline & & After 2 h (Sp 3) & After 4 h (Sp 4) & After 2 h (Sp 5) & After 4 h (Sp 6) \\
\hline & & $<\mathrm{DL}$ & $<\mathrm{DL}$ & $26.00 \pm 0.6^{*}$ & $36.00 \pm 0.8^{*}$ \\
\hline
\end{tabular}

All data represented as mean \pm SD

$<\mathrm{DL}$ mean less than detectable limit, the samples less than the limit ${ }^{*} p<0.05$

\subsection{Step B}

Lead acetate $\mathrm{Pb}\left(\mathrm{C}_{2} \mathrm{H}_{3} \mathrm{O}_{2}\right)_{3}$, was purchased from Sigma Company, Cairo, Egypt. Levels of exposure were set at $466.5 \mathrm{mg} / \mathrm{kg}$ body weight $(\mathrm{wt})\left(\mathrm{L}_{1}\right)$, while high level $\left(\mathrm{L}_{2}\right)$ of lead acetate $(\mathrm{Pb})$ equals $933.0 \mathrm{mg} / \mathrm{kg}$ body wt according to Subranamoorthy [10] and Nicholas and cheremisinoff [11].

Basal diet was formulated from the natural ingredients according to the National Research Council [12] with some modification according to Reeves et al. [13].

\subsubsection{Animals}

Thirty male albino rats weighing $118 \pm 5$ g were obtained from the National Research Center, Cairo, Egypt. All animals were offered food and water ad libitum throughout the experimental period. The rats were divided into three groups (10 rats each) as follows:

Group 1: fed on basal diet (negative control)

Group2: fed on basal diet $+466.5 \mathrm{mg} / \mathrm{kg}$ body wt of lead acetate $\left(\mathrm{L}_{1}\right)$

Group 3: fed on basal diet+933.0 $\mathrm{mg} / \mathrm{kg}$ body wt of lead acetate $\left(\mathrm{L}_{2}\right)$

During the experimental period (6 weeks) animals were inspected daily, and food intake and body wt were recorded twice/week. At the end of the experiment, the overnight-fasted rats were anesthetized, and blood samples were taken for biochemical analysis. Then, animals were scarified by cervical dislocation, with their livers and kidneys removed and weighed for determination of relative organ weight (organ/100 g live animal BW) and were prepared for histopathological examination. Rats in group 3 were found to have urinary bladder stones, and they were analyzed in a private medical laboratory; morphological characteristics were represented in results section. Food efficiency ratio (FER) was determined according to Chapman et al. [14].

\subsubsection{Biochemical analysis}

Estimation of serum total protein and albumin were carried out as described by Henry et al. [15] and Webster et al. [16], respectively. Globulin was calculated from the difference between total soluble protein and albumin concentrations. In addition, we assessed serum levels of glucose, glutamic oxaloacetic transaminase (GOT) and serum glutamic pyruvic transaminase (GPT), creatinine, urea, triglycerides, and cholesterol according to Tietz [17], Stanley and Sam [18], Henry and Canon [19], Patton and Crouch [20], Fossati and Principe [21], and Thomas [22], respectively. We determined hemoglobin (HB) concentration as described by Schalm [23] and erythrocyte count according to Wintrobe [24]. Serum lead concentration was estimated according to AOAC [9]. Livers and kidneys were dissected and prepared for histopathological examinations according to Drury and Wallington [25].

\subsubsection{Statistical analysis}

Water sample was analyzed using $T$ test according Excel 2010. However, blood sample was analyzed using ANOVA according to computer SPSS, 2015.

\section{Results}

\subsection{Step one result}

Lead concentrations in distilled water boiled in the unglazed clay pots and left to cool for either $2 \mathrm{~h}$ (Sp 3) or 4 h (Sp 4) showed no significant differences compared to the negative control (Sp 1). Whereas lead concentrations in distilled water samples boiled in glazed clay pots ( $\mathrm{Sp}$ 5 and Sp 6) were significantly $(p<0.05)$ higher $(26.00$ $\mu \mathrm{g} / \mathrm{L}$ and $36.00 \mu \mathrm{g} / \mathrm{L}$, respectively) than that of the negative control (Sp 1) as shown in Table 1.

Table 2 shows that lead concentrations in tap water (Sp 2) was $13.00 \mu \mathrm{g} / \mathrm{L}$. Its concentrations in boiling tap

Table 2 Concentrations of $\mathrm{Pb}$ in tap water boiled in clay pots

\begin{tabular}{|c|c|c|c|c|c|}
\hline \multirow{2}{*}{$\frac{\text { Parameters }}{\text { Groups }}$} & \multirow{2}{*}{$\begin{array}{l}\text { Tap water (Sp 2) (positive control) (Pb } \mu \mathrm{g} / \mathrm{L}) \\
13.00 \pm 2.3^{*}\end{array}$} & \multicolumn{2}{|c|}{ Clay pot natural (unglazed) (Sp 3) (Pb $\mu g / L)$} & \multicolumn{2}{|c|}{ Clay pot (ceramic with glaze) $(\mathrm{Pb} \mu \mathrm{g} / \mathrm{L})$} \\
\hline & & After $2 \mathrm{~h}(\mathrm{Sp} 7)$ & After 4 h (Sp 8) & After 2 h (Sp 9) & After $4 \mathrm{~h}(\mathrm{Sp} 10)$ \\
\hline & & $13.00 \pm 0.5^{*}$ & $16.00 \pm 0.3^{*}$ & $36.00 \pm 0.8^{*}$ & $52.00 \pm 0.6^{*}$ \\
\hline
\end{tabular}

All data represented as mean \pm SD

${ }^{*} p<0.01$ 
Table $\mathbf{3}$ The impact contaminated diet with lead to body weight gain (BWG), food intake (FI), and food efficiency ratio (FER) of rats for 6 weeks

\begin{tabular}{llll}
\hline Groups/parameters & BWG $(\mathrm{g})$ & $\mathrm{FI}(\mathrm{g})$ & FER $(\%)$ \\
\hline Group 1 negative control & $103.0 \pm 3.0$ & $12.3 \pm 0.9$ & $7 \pm 1.8$ \\
Group 2 $\mathrm{L}_{1} \mathrm{~Pb}$ & $76.0 \pm 3.0^{* *}$ & $8.93 \pm 0.5^{*}$ & $8 \pm 1.3$ \\
Group 3 $\mathrm{L}_{2} \mathrm{~Pb}$ & $55.0 \pm 7.0^{* *}$ & $7.75 \pm 0.5^{*}$ & $8 \pm 2.0$ \\
$p$ value & $p<0.01$ & $p<0.05$ & No sign.
\end{tabular}

All data represented as mean \pm SD

$\mathrm{L}_{1} \mathrm{~Pb}=466.5 \mathrm{mg} / \mathrm{kg}$ wt while $\mathrm{L}_{2} \mathrm{~Pb}=933 \mathrm{mg} / \mathrm{kg}$ wt

BWG = final body weight-initial body weight

FER $(\%)=$ body weight gain $(\mathrm{g}) /$ food intake $(\mathrm{g}) \times 100$

${ }^{*} p<0.05 ;{ }^{* *} p<0.01$

water in unglazed clay pots were 16.00 for both samples that were left to cool for $2 \mathrm{~h}$ (Sp 7) and $4 \mathrm{~h}$ (Sp 8), with a significant $(p<0.01)$ difference between them and the positive control (Sp 2). Tap water samples boiled in glazed clay pots (Sp 9 and Sp 10) showed lead concentrations that were significantly $(p<0.05)$ higher than that of the positive control.

\subsection{Step two results}

Table 3 shows that rats fed $L_{1}$ and $L_{2}$ of lead acetate had a significant $(p<0.05)$ decrease in BWG and food intake compared with the negative control group. The data yielded in Table 4 indicate that the weight of liver, spleen, and testis of rats ingested lead acetate at two levels have increased significantly $(p<0.05)$ in both levels compared with the negative control, except the weight of the heart was decreased significantly $(p<0.05)$ in comparison with negative control.

Table 5 shows that rats administered lead at the two doses $\left(\mathrm{L}_{1}\right.$ and $\left.\mathrm{L}_{2}\right)$ had significantly lower levels of hemoglobin $(p<0.01)$, RBCs $(p<0.01)$, and WBCs $(p<$ $0.05)$ compared with rats fed basic diet only (negative control). However, rats fed high-dose lead had significantly lower levels of hemoglobin, RBCs, and WBCs compared with those fed low-dose lead. Rats given lead had significantly $(p<0.05)$ lower percentages of lymphocyte and reticulocytes compared with the negative control rats. Monocytes percentage was significantly $(p<$ 0.05 ) lower in group 3 compared with group 2 and negative control. Concerning the percentage of neutrophils did not significantly differ between the three groups.

Table 6 shows that rats given lead $\left(\mathrm{L}_{1}\right.$ and $\left.\mathrm{L}_{2}\right)$ had significant $(p<0.05)$ reduction in the levels of total protein, albumin, globulin, and glucose compared with negative control rats.

Data in Table 6 illustrate the blood cholesterol and triglycerides levels. Results indicated that the animals of the group fed on $\mathrm{Pb}$ at $\mathrm{L}_{1}$ had a significant increase in cholesterol and triglycerides levels $(p<0.01)$ with a mean value of $93.0 \pm 0.1$ and $74.4 \pm 0.7 \mathrm{mg} / \mathrm{dL}$, compared to the negative control $85.4 \pm 0.3$ and $42.2 \pm 0.6$ $\mathrm{mg} / \mathrm{dL}$, respectively. And vice versa, results of blood cholesterol and triglyceride levels of the group fed on $\mathrm{Pb}$ at $\mathrm{L}_{2}$ had shown decreased significantly $(p<0.01)$ compared with other groups.

Table 7 report that rats fed the basal diet plus lead acetate at both low and high levels $\left(\mathrm{L}_{1}\right.$ and $\left.\mathrm{L}_{2}\right)$ had significantly $(p<0.01)$ increased creatinine and urea concentrations compared to the negative control group. Similarly, lead-fed rats $\left(\mathrm{L}_{1}\right.$ and $\left.\mathrm{L}_{2}\right)$ had significantly $(p<$ 0.001 ) increased GOT serum concentrations with mean values of $14.6 \pm 1.2$ and $11.9 \pm 1.2 \mathrm{U} / \mathrm{L}$, respectively, compared to the negative control $(5.80 \pm 0.7 \mathrm{U} / \mathrm{L})$. GPT serum concentrations were significantly $(p<0.05)$ lower in lead-fed animals $\left(\mathrm{L}_{1}\right.$ and $\left.\mathrm{L}_{2}\right)$ with mean values of 11.7 \pm 0.9 and $10.7 \pm 1.7 \mathrm{U} / \mathrm{L}$, respectively, compared to the negative control animals $(12.8 \pm 0.5 \mathrm{U} / \mathrm{L})$.

Animals given lead acetate that was added to the basal diet $\left(\mathrm{L}_{1}\right.$ and $\left.\mathrm{L}_{2}\right)$ had significantly $(p<0.001)$ increased serum lead concentrations at level one and two with mean values of $21.25 \pm 0.8 \mu \mathrm{g} / 100 \mathrm{~cm}^{3}$ and $25.64 \pm 1.3$ $\mu \mathrm{g} / 100 \mathrm{~cm}^{3}$, respectively, compared with rats given only basal diet (Fig. 3).

The report of the urinary calculus analysis shows that the stone was one large, oval-shaped, appearing in light color, with dimensions of $2 \times 1.5 \mathrm{~cm}$, and a weight of 1.5 g. Its chemical composition was calcium phosphate.

\subsection{Histopathology results}

Figure 4 a represents a liver section from a control rat showing the normal liver structure, with a central vein

Table 4 Effect contaminated diet with lead acetate on organs (liver, kidney, brain, spleen, testes, and heart) relative weight of rats

\begin{tabular}{|c|c|c|c|c|c|c|}
\hline Parameters & Liver (g) & Kidney (g) & Brain (g) & Spleen (g) & Testis (g) & Heart (g) \\
\hline Group1 negative control & $3.30 \pm 0.24$ & $0.74 \pm 0.04$ & $0.87 \pm 0.07$ & $0.41 \pm 0.04$ & $1.46 \pm 0.27$ & $0.46 \pm 0.05$ \\
\hline Group $2 \mathrm{~L}_{1} \mathrm{~Pb}$ & $3.53 \pm 0.25^{*}$ & $0.88 \pm 0.08$ & $0.74 \pm 0.11$ & $0.45 \pm 0.06^{*}$ & $1.84 \pm 0.17^{*}$ & $0.38 \pm 0.03^{*}$ \\
\hline Group $2 \mathrm{~L}_{2} \mathrm{~Pb}$ & $3.90 \pm 0.28^{*}$ & $0.84 \pm 0.12$ & $0.87 \pm 0.05$ & $0.64 \pm 0.16^{*}$ & $2.03 \pm 0.33^{*}$ & $0.36 \pm 0.03^{*}$ \\
\hline$p$ value & $p<0.05$ & No sign. & No sign. & $p<0.05$ & $p<0.05$ & $p<0.05$ \\
\hline
\end{tabular}

All data represented as mean $\pm \mathrm{SD}$

$\mathrm{L}_{1} \mathrm{~Pb}=466.5 \mathrm{mg} / \mathrm{kg}$ wt while $\mathrm{L}_{2} \mathrm{~Pb}=933 \mathrm{mg} / \mathrm{kg}$ wt

Organs relative body weight $=$ organs weight/final body weight

${ }^{*} p<0.05$ 
Table 5 Effect contaminated diet with lead acetate on hemoglobin ( $\mathrm{g} / \mathrm{dL})$, erythrocytes (RBCs count), total leukocyte count $\left(10^{3} / \mu \mathrm{L}\right)$, and differential percentage of rats

\begin{tabular}{|c|c|c|c|c|c|c|c|}
\hline Parameters & Hemoglobin (g/dL) & RBCs $(\mathrm{mil} / \mu \mathrm{L})$ & Total leukocyte WBCs $\left(10^{3} / \mu \mathrm{L}\right)$ & Lymphocyte (\%) & Neutrophils (\%) & Monocytes (\%) & Reticulocytes (\%) \\
\hline Groups G1 & $12.88 \pm 0.08$ & $4.27 \pm 0.02$ & $7018.6 \pm 642.00$ & $56.00 \pm 1.1$ & $32.00 \pm 1.3$ & $3.00 \pm 0.20$ & $7.00 \pm 1.1$ \\
\hline $\begin{array}{l}\text { Group } 2 \\
L_{1} \mathrm{~Pb}\end{array}$ & $12.23^{* *} \pm 0.09$ & $4.07 \pm 0.02^{* *}$ & $6941.9^{*} \pm 506.7$ & $53.70^{* *} \pm 1.8$ & $32.07 \pm 1.0$ & $3.00 \pm 0.58$ & $5.02^{* *} \pm 0.58$ \\
\hline $\begin{array}{l}\text { Group } 3 \\
L_{2} \mathrm{~Pb}\end{array}$ & $11.24^{* *} \pm 0.16$ & $3.74^{* *} \pm 0.05$ & $5942.0^{*} \pm 505.2$ & $55.00^{* *} \pm 0.70$ & $32.00 \pm 1.3$ & $2.00^{* *} \pm 0.30$ & $5.03^{* *} \pm 0.68$ \\
\hline$p$ value & $p<0.05$ & $p<0.01$ & $p<0.05$ & $p<0.01$ & No sign. & $p<0.05$ & $p<0.01$ \\
\hline
\end{tabular}

All data represented as mean \pm SD

$\mathrm{L}_{1} \mathrm{~Pb}=466.5 \mathrm{mg} / \mathrm{kg}$ wt while $\mathrm{L}_{2} \mathrm{~Pb}=933 \mathrm{mg} / \mathrm{kg}$ wt

${ }^{*} p<0.05 ;{ }^{* *} p<0.01$

(CV) surrounded by hepatocytes (HC) (H \& E stain, X 300).

Liver sections from rats given lead at a low dose shows portal tracts with dilated, congested veins $(\nearrow)$, periportal necrosis of hepatocytes surrounding the portal area $(\triangleright)$ as well as inflammatory infiltration ( $\Uparrow$ ) (Fig. 4b) (H \& E stain, X 150).

Liver sections from rats administered high-dose lead show portal tracts and periportal spaces $(\uparrow)$, periportal necrosis of hepatocytes that surround the portal area $(\triangleright)$, and some nuclei are pyknotic $(\nabla)$ and inflammatory infiltration ( $\uparrow$ ) (Fig. 4c) (H \& E stain-X 300).

Figure 5 a shows a section in a control rat kidney with normal structure (H \& E stain, X 300).

Kidney sections from rats fed lower doses of lead show renal corpuscle congestion and hypercellular (*). Observed the highly ale generated tubules $(\nabla)$. Also, notice the shrinkage of an anther one associated with wide urinary space ( $\searrow$ ) (Fig. 5b) (H \& E stain, X 300).

Figure $5 \mathrm{c}$ represents a kidney section from rats fed higher doses of lead. It shows hemorrhagic areas in the interstitium $(\uparrow)$ and inflammatory infiltration beside the congested renal corpuscle $\left(^{*}\right)$. The notice shows the denigration of the renal tubules (\#) (H \& E stain, X 300).

\section{Discussion}

From ancient to recent century, people were used to cooking in clay pots. Our study investigated the lead concentration in the water was boiled in two kinds of clay pots (glazed and unglazed). The results concerning the best kind of clay for cooking a clay pot were unglazed as natural form (Fig. 1). Whether the glazed layer in the local market is contaminated with lead is reported by the FDA [2].

Lead may be present in the glazes or decorations covering the surface of some traditional pottery. If the pottery is not manufactured properly, this lead can leach into food and drink that is prepared, stored, or served in the dishes. Loading food of $\mathrm{Pb}$ differs according to the cooking method and the acidity of food and time.

Our results show that lead concentrations in distilled water boiled in glazed clay pots were 26.00 and 36.00 $\mu \mathrm{g} / \mathrm{L}$ at $2 \mathrm{~h}$ and $4 \mathrm{~h}$, respectively, which are significantly higher than its concentrations in the negative control water sample. These results explain the distilled water contaminated by lead carried out from the glazed layer of a clay pot. A previous case was a report of a woman presenting to the hospital with nonspecific chronic abdominal pain and unexplained anemia. She was suspected of having lead toxicity, and hence blood lead level was ordered. The lead concentration in her blood was markedly elevated. Her son had also an elevated blood lead level. Both the patient and her son had substantial lead exposure as they were using ceramic pots and mugs, whose glaze covering was found to have $17 \%$, the lead by weight [26].

Diaz-Ruiz et al. [27] used clay containers to prepare and store lemonade, which was supplied as drinking water to pregnant rats throughout the gestational period. They found that these containers leached about $200 \mu \mathrm{g} /$

Table 6 Effect of adding lead acetate in basic diet on total protein, albumin, globulin, glucose, cholesterol, and triglycerides concentration in serum

\begin{tabular}{lllllll}
\hline Parameters/groups & Total protein $(\mathrm{g} / \mathrm{dL})$ & Albumin $(\mathrm{g} / \mathrm{dL})$ & Globulin $(\mathrm{g} / \mathrm{dL})$ & Glucose $(\mathrm{mg} / \mathrm{dL})$ & Cholesterol $(\mathrm{mg} / \mathrm{dL})$ & Triglycerides $(\mathrm{mg} / \mathrm{dL})$ \\
\hline Group 1 negative control & $5.67 \pm 0.14$ & $4.09 \pm 0.04$ & $1.67 \pm 0.2$ & $85.6 \pm 0.50$ & $85.4 \pm 0.3$ & $42.2 \pm 0.6$ \\
Group $2 \mathrm{~L}_{1} \mathrm{~Pb}$ & $5.14^{* *} \pm 0.22$ & $4.47 \pm 0.21^{* *}$ & $0.54 \pm 0.18^{* *}$ & $69.8 \pm 0.90^{* *}$ & $93.6 \pm 0.1^{* *}$ & $74.4 \pm 0.7^{* *}$ \\
Group $3 \mathrm{~L}_{2} \mathrm{~Pb}$ & $4.84^{* *} \pm 0.23$ & $3.7 \pm 0.13^{* *}$ & $1.04 \pm 0.31^{* *}$ & $72.00 \pm 1.4^{* *}$ & $84.4 \pm 0.1^{* *}$ & $59.6 \pm 0.5^{* *}$ \\
$p$ value & $p<0.01$ & & & & \\
\hline
\end{tabular}

All data represented as mean $\pm \mathrm{SD}$

$\mathrm{L}_{1} \mathrm{~Pb}=466.5 \mathrm{mg} / \mathrm{kg}$ wt while $\mathrm{L}_{2} \mathrm{~Pb}=933 \mathrm{mg} / \mathrm{kg}$ wt

${ }^{*} p<0.05$; ${ }^{* *} p<0.01$ 
Table 7 The effect of adding lead acetate (at two levels) in the diet on kidney and liver function parameters in serum of rats

\begin{tabular}{lllll}
\hline Parameters & Kidney function & & Liver function \\
\cline { 2 - 3 } Groups & Creatinine $(\mathrm{mmol} / \mathrm{L})$ & Urea $(\mathrm{mg} / \mathrm{dL})$ & & GOT $(\mathrm{U} / \mathrm{L})$ \\
\hline Group1 negative control & $0.62 \pm 0.01$ & $31.09 \pm 0.13$ & $3.8 \pm 0.7$ & $14.6 \pm 1.2^{* * *}$ \\
Group 2 $\mathrm{L}_{1} \mathrm{~Pb}$ & $1.80 \pm 0.02^{* *}$ & $39.72 \pm 0.15^{* *}$ & & $12.8 \pm 0.5$ \\
Group 2 ${ }_{2} \mathrm{~Pb}$ & $2.00 \pm 1.20^{* *}$ & $39.18 \pm 0.14^{* *}$ & $11.9 \pm 1.2^{* * *}$ & $1.7 \pm 0.9^{*}$ \\
$p$ value & $p<0.01$ & $p<0.01$ & $p<0.001$ & $10.7 \pm 1.7^{*}$ \\
\hline
\end{tabular}

All data represented as mean \pm SD

$\mathrm{L}_{1}=466.5 \mathrm{mg} / \mathrm{kg}$ wt while $\mathrm{L}_{2}=933 \mathrm{mg} / \mathrm{kg}$ wt

${ }^{*} p<0.05 ;{ }^{* *} p<0.01$; ${ }^{* * *} p<0.001$

L lead. Moreover, pregnant rats had elevated lead levels in their blood $(2.5 \mu \mathrm{g} / \mathrm{dL})$. Examination of the neonates' brain revealed increased lead content in the hippocampus and cerebellum.

Our results indicated that distilled water boiled and stored for $2 \mathrm{~h}$ and $4 \mathrm{~h}$ in unglazed clay pots had lead concentrations less than the detectable limits. Tap water that was prepared in unglazed clay pots had the same level of lead found in tap water with no significant difference between 2 and $4 \mathrm{~h}$. The advert results of tap water were prepared in a clay pot (glazed), resulting to a significant increase in lead concentration of about 36.00 and $52.00 \mu \mathrm{g} / \mathrm{dL}$ through $2 \mathrm{~h}$ and $4 \mathrm{~h}$, respectively. Anyway, the tolerable admission level of lead in a review of the latest scientific evidence was $25 \mu \mathrm{g} / \mathrm{kg}$ BW per week [5].

Lead is a far-reaching and non-biodegradable poison that is critically dangerous to human beings, with several sources for exposure. Therefore, our study results in Step B aimed to assess its toxicity. In the present study, rats fed $L_{1}$ and $L_{2}$ of lead acetate had a significant decrease in BWG and food intake compared with the negative control. This could be due to the toxicity induced on the gastro-intestinal tract as manifested by symptoms such as colic, diarrhea, nausea, and loss of appetite, which agreed with the findings of the WHO [28].

Ebrahimi et al. [29] reported that lead-induced oxidative stress adversely suppresses feed efficiency and growth performance in chicken. On the other hand, our data illustrated that the weights of the liver, spleen, and testes of rats given lead acetate at two levels were significantly $(p<0.05)$ higher compared with the negative control. This result is compatible with that of the liver enzymes. Where lead-fed rats $\left(\mathrm{L}_{1}\right.$ and $\left.\mathrm{L}_{2}\right)$ had significantly $(p<0.001)$ increased GOT serum concentrations compared to the negative control, but GPT serum concentrations were significantly $(p<0.05)$ lower in lead-fed animals $\left(\mathrm{L}_{1}\right.$ and $\left.\mathrm{L}_{2}\right)$ compared to the negative control animals. Furthermore, histopathological examination of liver sections from lead-fed rats $\left(\mathrm{L}_{1}\right.$ and $\left.\mathrm{L}_{2}\right)$ showed portal tracts with dilated, congested veins, periportal necrosis of hepatocytes, and cellular inflammatory infiltration.

On the other hand, the effect of toxicity induced by lead at the two levels of exposure on total organs relative weight (liver, kidney, brain, spleen, testes, and heart) varied depending upon the type of organ affected, adverse effects of lead toxicity, type of administration, and doses administered.

Our data illustrated that rats were given lead acetate at the two levels $\left(\mathrm{L}_{1}\right.$ and $\left.\mathrm{L}_{2}\right)$ had significantly lower levels of hemoglobin, RBCs, and WBCs compared with rats fed the basic diet only (negative control). This agrees with Gargouri et al. [30] who reported that rats treated with lead at doses of $0.344 \mathrm{~g} / \mathrm{kg}$ BW for 30 days had renal damage with significant increases in hematological parameters, oxidative stress-related parameters, creatinine, urea levels in plasma, and uric acid level in urine. Also,

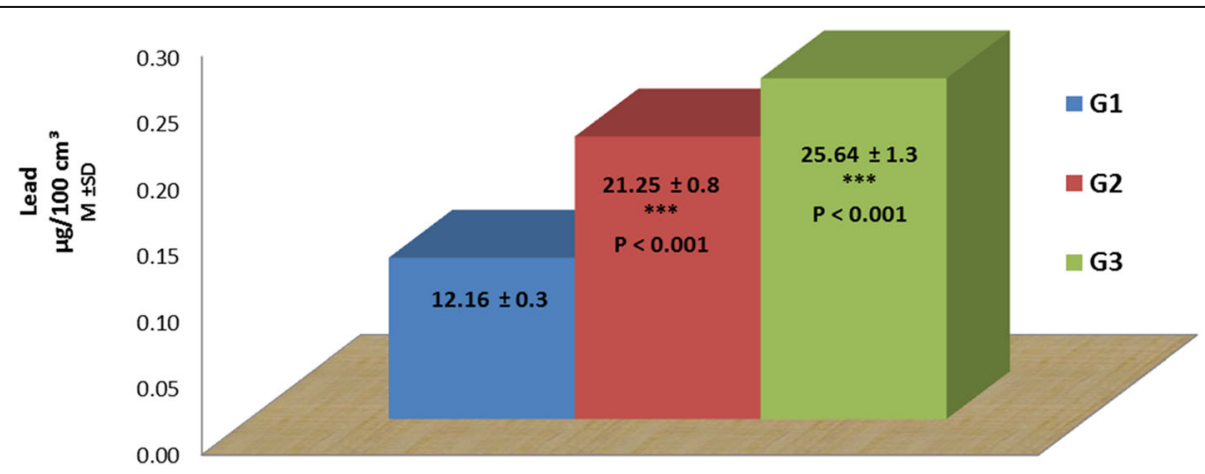

Fig. 3 The effect of adding lead at two levels in the diet on lead concentration in serum of rats 


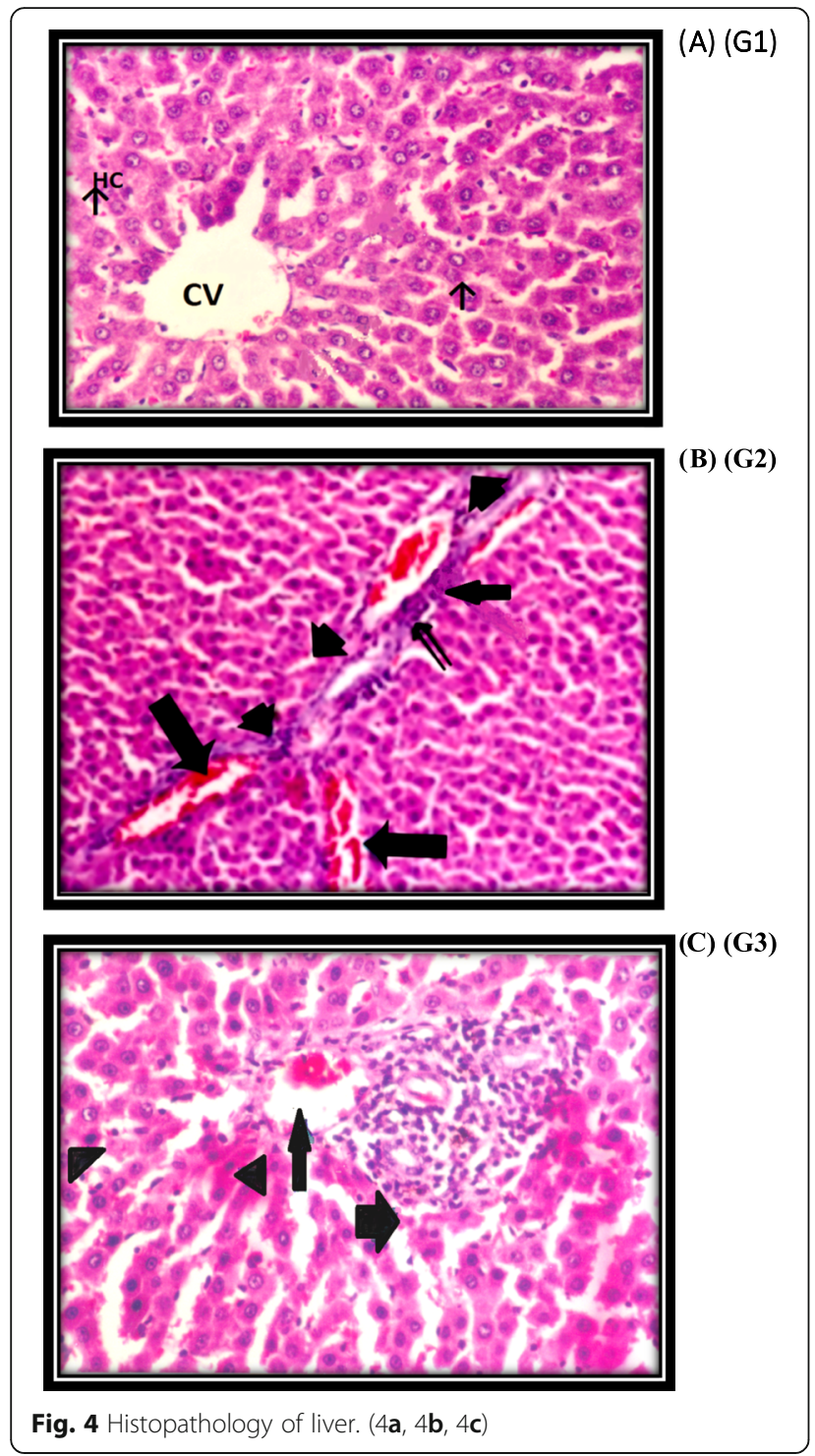

the WHO [5] and Assi et al. [31] emphasized that chronic lead exposure commonly causes hematological effects, like anemia, or neurological disturbances, including headache, irritability, lethargy, convulsions, muscle weakness, ataxia, tremors, and paralysis.

In the current study, the differential count of white blood cells (lymphocytes, reticulocytes, and monocytes) as well as total protein, albumin, globulin, and glucose levels showed a significant reduction in rats fed either doses of lead acetate $\left(\mathrm{L}_{1}\right.$ and $\left.\mathrm{L}_{2}\right)$ compared with the negative control rats. This goes hand in hand with Kim et al. [32] who found reduced plasma protein level with prolonged starvation in humans and malabsorption syndrome because of some intestinal diseases such as sprue liver disease that may result in depression of protein synthesis and enhancement of albumin loss in urine.

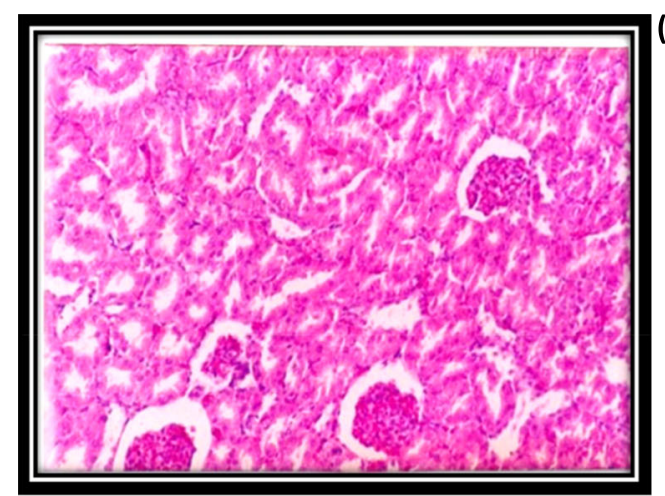

(A) (G1)

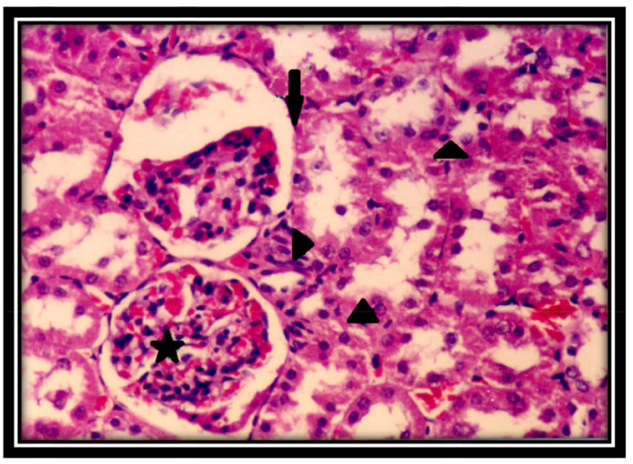

(B) (G2)

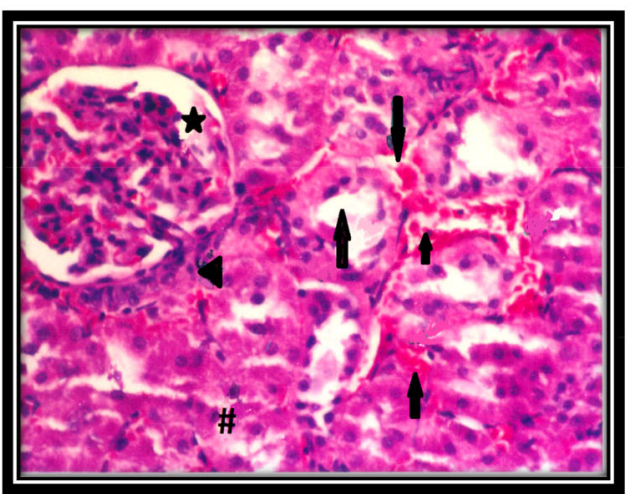

(C) (G3)

Fig. 5 Histopathology of kidney. (5a, 5b, 5c)

Our results indicated that animals fed low-dose lead had a significant $(p<0.01)$ increase in cholesterol and triglycerides levels with mean values of $93.0 \pm 0.1$ and $74.4 \pm 0.7 \mathrm{mg} / \mathrm{dL}$, compared to the negative control which had mean values of $85.4 \pm 0.3$ and $42.2 \pm 0.6 \mathrm{mg} /$ $\mathrm{dL}$, respectively. On the other hand, blood cholesterol and triglycerides levels in animals fed high-dose lead showed a significant $(p<0.01)$ reduction compared with other groups. Our interpretation of these results is that rats in group 3 had the lowest BWG and FI compared with other groups. Our finding was compatible with Kasperczyk et al. [33] who reported no significant changes in the concentration of 7-ketocholesterol and blood lipids (cholesterol, HDL, LDL, triglycerides) in blood workers exposed to lead at level one $(25-40 \mu \mathrm{g} /$ $\mathrm{dL})$ and level two $(40 \mu \mathrm{g} / \mathrm{dL})$. 
In our study, rats fed the basal diet plus lead acetate at both low and high levels $\left(\mathrm{L}_{1}\right.$ and $\left.\mathrm{L}_{2}\right)$ had significantly increased concentrations of creatinine and urea in serum compared to the negative control group. These results coincide with the histopathology results; however, an examination of sections from kidneys of rats fed lowdose lead $\left(\mathrm{L}_{1}\right)$ showed renal corpuscle congestion and shrinkage of an anther one associated with wide urinary space and highly ale generated tubules. Kidney sections from rats fed high-dose lead $\left(\mathrm{L}_{2}\right)$ showed hemorrhagic areas, inflammatory infiltration, and congested renal corpuscle as well as the denigration of the renal tubules. In addition, we found urinary stones in the bladder of a few rats that were fed a high level of lead $\left(\mathrm{L}_{2}\right)$. Chemical analysis of these stones revealed that they were formed of calcium phosphates. This could be interpreted in light of our finding of high blood lead concentration in rats fed high-dose lead $\left(\mathrm{L}_{2}\right)$ with a mean value of $25.64 \pm 0.40$ $\mu \mathrm{g} / 100 \mathrm{~cm}^{3}$. These may result from unabsorbed calcium and vitamin $\mathrm{D}$ in the small intestine that caused their deposition in urine and formation of the stones. Previous studies had shown a strong association between lead exposure and renal effects [34,35]. The hidden effects of childhood lead exposure include chronic advanced renal disease or reduction in renal function in adulthood. However, continued or repetitive exposures to lead can cause decreases in the estimated glomerular filtration rate and creatinine clearance, which may develop into chronic and often irreversible lead nephropathy [36]. Dongre et al. [7] reported that lead impaired normal kidney functions. Significantly decreased total calcium, phosphorus, vitamin $\mathrm{D}$, and bone mineral density and significantly increased parathyroid hormone are observed in workers in battery manufacture as compared to the control group. Potula et al. [37] and Sun et al. [38] reported that lead inhibits 1- $\alpha$ hydroxylase enzyme in renal tubules, which is required for calcitriol formation. Also, calcitriol plays a crucial role to maintain homeostasis of calcium and phosphorus metabolism.

Finally, there are many studies that reported the side effects and the huge problem associated with exposure to lead. Abdou and Hassan [39] and Missoun et al. [40] reported that lead acetate in drinking water for 8 weeks administered by the oral route caused a renal deficiency in the affected rats.

\section{Conclusion}

Bringing the clay pot for cooking would be unglazed and natural forming, even if glazed may have been certified to be lead free in order to decrease the side effect caused by lead.

Try to decrease the exposed sources of lead at dusk or food contaminated with lead, so they avoid the side effects of lead on body weight, food efficiency, anemia, and weakened immunity and change the biochemical parameters in blood.

\section{Acknowledgements}

The authors would like to acknowledge the subjects who helped them to collect the water samples in stage one of the study and the teams in Desert Research Center, Cairo, Egypt, and finally thank the team in lab creature generation unit of Research Institute of Ophthalmology, Giza, Egypt

\section{Authors' contributions}

MS prepared the samples, clay pots, and water analysis in stage one of the experiment and made nutritional and biochemical analysis studies in stage two as well as writing. ELG prepared animals in stage two, helped in feeding and obtained organs for the histopathology results. The authors read and approved the final manuscript.

Funding

We do not have any fund in this paper.

\section{Availability of data and materials}

Not applicable

Ethics approval and consent to participate

The protocol was approved by the local Ethics Committee for Animal Studies of the Ain Shams University of Cairo, Egypt (AESC/RECS/2017/03/12).

Consent for publication

Every author approved to publication.

Competing interests

The authors declare that they have no competing interests.

Received: 19 November 2019 Accepted: 12 March 2020

Published online: 10 June 2020

\section{References}

1. Paranjape M, Kulkarni S (2018) A comparative shelf life study of food cooked in aluminum pot and unglazed earthen clay pot- International Journal of Food Science and Nutrition ISSN: 2455-4898.

2. U.S. Food and Drug Administration FDA (2010) Guidance for industry: safety of imported traditional pottery intended for use with food and the use of the term "lead free" in the labeling of pottery/proper identification of ornamental and decorative ceramic ware. Environmental Assessment for Food Contact Notification FCN 1659

3. Erdogan Z, Erdogan S, Celik S, Unlu A (2005) Effects of ascorbic acid on cadmium-induced oxidative stress and performance of broilers. Biol Trace Elem Res 104(1):19-31

4. Yasemin B, Susana Rio S, Emily R Yourd and Julian F Tyson(2003) Evaluation of $\mathrm{Pb}$-Spec ${ }^{\circledR}$ for flow-injection solid-phase extraction preconcentration for the determination of trace lead in water and wine by flame atomic absorption spectrometry, Anal Chim Acta, ISSN: 0003-2670, Vol: 485, Issue: 1, Page: 9-18

5. WHO (2010) Quantifying environmental health impacts. World Health Organization, Geneva. http://www.who.int/quantifying_ehimpacts/en/

6. Memoh SQ, Hasany SM, Bhanger MI, Khuhawar MY (2005) Enrichment of Pb (II) ions using phthalic acid functionalized XAD - 16 Resin as a Sorbent. J Colliod Inter Sci 29:84

7. Dongre NN, Suryakar AN, Patil AJ, Hundekari IA, Devarnavadagi BB (2013) Biochemical effects of lead exposure on battery manufacture workers with reference to blood pressure, calcium metabolism and bone mineral density. Indian J Clin Biochem 28(1):65-70. https://doi.org/10.1007/s12291-012-0241-8

8. Matoso E, Kubota LT, Cadore S Talanta (2003) vol 60, 1105.

9. Association of Official Analytical Chemists AOAC (2019) Official Methods of Analysis, 21th ed., Washington,U.S.A. www.aoac.org

10. Sub Ramamoorthy, E.G. Baddaloo, (1995) Handbook of chemical toxicity profilees of biological species. Vol 11 , avlan and mamallom species.pp 5060.

11. Nicholas P Cheremisinoff (1999) Handbook of industrial toxicology and hazardous materials. Health Risk information of Lead Acetate. CRC Press. ISBN 9780824719357- PP 589-596. 
12. National Research Council (1995) Nutrient requirement of laboratory animals, general considerations for feeding and diet formulation. National academy press.Washington,D.C. U.S.A. PP 3- 50.

13. Reeves BG, Nielson FH, Fahmy GC (1993) Reported of the American Institute of nutrition. Adhoc- wrilling committee on the reformulation of the A.I.N. 1979-Ardent Diet. J.Nutr 123:1939-1951

14. Chapman DG, Raul Castillo, JA Campbell (1959) Evaluation of protein in food. IA Method for the determination of protein efficiency ratio. Can J Biochem Physiol, 1959, 37:679-686, https://doi.org/10.1139/059-074

15. Henry RJ Harper and Row (1964) Colorimetric determination of total protein: Clinical Chemistry; New York. p. 181.

16. Webster D, Bignell A H, Attwood EC (1974) An assessment of the suitability of bromocresol green for the determination of serum albumin. Clin Chim Acta. May 31;53(1):101-108

17. Tietz, NW (1986) Textbook of Clinical Chemistry W.B. Saunders Co. London Pheladelphia. ISBN 0-7216-8886-1- P,796.

18. Stanley R, Sam F (1957) A colorimetric method for the determination of serum glutamic oxalacetic and glutamic pyruvic transaminases. Am J Clin Pathol 28(1):56-63 https://doi.org/10.1093/ajcp/28.1.56

19. Henry RJ, Canon DC, (1974) Winkelman JW. Clinical chemistry: principles and technics, 2nd Ed, Harper and Row Publishers.

20. Patton C J, \& Crouch SR (1977) Anal Chem., 49:464-469.

21. Fossati P, Prencipe $L$ (1982) Serum triglycerides determined colorimetrically with an enzyme that produces hydrogen peroxide. Clin Chem 28:20772080

22. Thomas L (1992) Labor and Diagnose, Indikation und Bewertung von Laborbefunden für die medizinische Diagnostik. Die Medizinische Verlagsgesellschaft. Marburg. 4th .ed

23. Schalm OW (1986) Veterinary haematology. 4th Ed. Lea and Febiger, Philadelphia, pp 21-86

24. Wintrobe MM (1967) A hematological odyssey, 1926-66. Johns Hopkins Medical Journal 120:287-309

25. Drury RAB \& Wallington E A (1980) Carleton's histological techniques- $5^{\text {th }}$ ed. oxford: Oxford University press. PP. 403-4-6

26. Fralick M, Thomspson A, Mourad O (2016) Lead toxicity from glazed ceramic cookware. CMAJ: Canadian Medical Association journal = journal de I'Association medicale canadienne 188(17-18):E521-E524. https://doi.org/10. 1503/cmaj.160182

27. Diaz-Ruiz A, Tristán-López L A, Medrano-Gómez K I, Torres-Domínguez J A, Ríos C, Montes S (2017) Glazed clay pottery and lead exposure in Mexico: current experimental evidence. Nutr. Neurosci. 20, 513-518. 10.1080/ 1028415x.2016.1193967 [PubMed] [CrossRef] [Google Scholar]

28. WHO (World Health Organization) (1997) Inorganic Lead. Environmental Health Criteria no. 165, Geneva.

29. Ebrahimi R, Jahromi MF, Liang JB, Soleimani AF, Shokryazdan P, Idrus Z (2015) Effect of dietary lead on intestinal nutrient transporters mRNA expression in broiler chickens. BioMed Research Int. https://doi.org/10.1155/ 2015/149745

30. Gargouri M, Soussi A, Akrouti A, Magné C, El Feki A (2018) Ameliorative effects of spirulina platensis against lead-induced nephrotoxicity in newborn rats: modulation of oxidative stress and histopathological changes. EXCLI J 17:215-232

31. Assi MA, Hezmee MN, Haron AW, Sabri MY, Rajion MA (2016) The detrimental effects of lead on human and animal health. Veterinary world 9(6):660-671. https://doi.org/10.14202/vetworld.2016.660-671

32. Kim E, Barrett, Scott B, Susan M Barman, Heddwen L (1996) Ganong's review of medical physiology- section 1 Copyright @ 2010 by The McGraw-Hill Companies, Inc. All rights reserved. Except as permitted under the United States Copyright Act of 1976 p. 363.

33. Kasperczyk S, Birkner E, Kasperczyk A, Kasperczyk J (2005) Lipids, lipid peroxidation and 7-ketocholesterol in workers exposed to lead- Human \& Experimental Toxicology-volume 24 Issue 6- no. 6, pp. 287-295.

34. Agency for Toxic Substances and Disease Registry ATSDR (2015) Taking an Exposure History. Atlanta, GA: Department of Health and Human Services CASE STUDIES IN ENVIRONMENTAL MEDICINE. U.S. Department of Health and Human Services Agency for Toxic Substances and Disease Registry Division of Toxicology and Human Health Sciences Environmental Medicine Branch

35. National Toxicology Program. NTP (2012) Monograph on Health Effects of Low-Level Lead. Research. National Institutes of Health NIH Publication No. 12-5996 ISSN 2330-1279.
36. Landrigan PJ, Etzel RA (2013) Textbook of children's environmental health. London: Oxford University Press, November 2013.

37. Potula V, Henderson A, Kaye W (2005) Calcitropic hormones, bone turn over and lead exposure among female smelter workers. Arch Environ Occup Health.;60(4):195-204. doi: 10.3200/AEOH.60.4.195-204. [PubMed] [CrossRef] [Google Scholar]

38. Sun Y, Sun D, Zhou Z, Zhu G, Zhang H, Chalng X, Lei L, Jin T. (2008) Osteoporosis in a Chinese population due to occupational exposure to lead. Am J Ind Med. 51:436-442. doi: 10.1002/ajim.20567. [PubMed] [CrossRef] [Google Scholar]

39. Abdou HM, Hassan MA (2014) Protective role of omega-3 polyunsaturated fatty acid against lead acetate-induced toxicity in liver and kidney of female rats. Biomed Res Int 2014:435857-435857

40. Missoun F \& Slimani M and Aoues A (2010) Toxic effect of lead on kidney function in rat Wistar. African Journal of Biochemistry Research. 4. 21-27.

\section{Publisher's Note}

Springer Nature remains neutral with regard to jurisdictional claims in published maps and institutional affiliations.

\section{Submit your manuscript to a SpringerOpen ${ }^{\circ}$ journal and benefit from:}

- Convenient online submission

- Rigorous peer review

- Open access: articles freely available online

- High visibility within the field

- Retaining the copyright to your article

Submit your next manuscript at $\boldsymbol{\nabla}$ springeropen.com 